\title{
PENGARUH PROFITABILITAS, LEVERAGE, DAN UKURAN PERUSAHAAN TERHADAP PENGHINDARAN PAJAK PADA PERUSAHAAN FARMASI DI BEI
}

\author{
Mohammad Taufik Azis ${ }^{1)}$, Isra Umami Widianingsih ${ }^{2)}$ \\ ${ }^{1,2)}$ Fakultas Ekonomi, Universitas Muhammadiyah Cirebon \\ Email: taufik.azis@umc.ac.id
}

\begin{abstract}
Abstrak
Perusahaan akan mengurangi biaya pajak untuk meningkatkan laba perusahaan, sehingga diharapkan dengan penghindaran pajak ini dapat meningkatkat kinerja keuangan. Tujuan perusahaan ini adalah untuk mengetahui profitabilitas, laverage dan ukuran perusahaan terhadap penghindaran pajak. Penelitian ini dilakukan pada perusahaan farmasi di Bursa Efek Indonesia dari tahun 2015 sampai 2019 dengan populasi penelitian 50 perusahaan dan diperolah sampel perusahaan 40 perusahaan. Pengujian hipotesis dilakukan dengan teknik analisis regresi linier berganda. penelitan ini mendapatkan hasil, yaitu : profitabilitas berpengaruh negatif terhadap penghindaran pajak, sedangkan Laverage dan Ukuran perusahaan tidak berpengaruh terhadap penghindaran
\end{abstract}

Kata kunci: Profitabilitas, Laverage, Ukuran perusahaan, penghindaran pajak

\section{PENDAHULUAN}

Sumber pendapatan negara yang paling besar adalah Pajak. Karena pajak merupakan kontribusi wajib bagi rakyat kepada negara yang bersifat memaksa dengan tidak mendapatkan imbalan secara langsung dan digunakan untuk kepentingan negara demi kemakmuran rakyat. Untuk sistem pemungutan pajak yang diterapkan di indonesia yaitu menggunakan Self assessment system, dimana wajib pajak diberikan wewenang untuk menentukan sendiri besarnya pajak yang terutang. Sehingga terdapat perbedaan kepentingan antara wajib pajak dengan pemerintah. Dimana wajib pajak terutama perusahaan berusaha agar membayar pajak sekecilkecilnya. Dengan perbedaan kepentingan ini akan timbul usaha pengurangan (penghematan) pajak yang dapat dilakukan dengan berbagai cara misalnya dengan penggelapan pajak (tax evasion) dan penghindaran pajak (tax avoidance). 
Liem (2011), mendefinisikan Tax Avoidance (penghindaran pajak) sebagai kebijakan perusahaan untuk meminimalkan kewajiban pajak. Tindakan penghindaran pajak tentu saja akan mengurangi kas negara dan akan mempengaruhi APBN. Penerimaan pajak direncanakan sedemikian rupa untuk mencapai target yang diharapkan dalam penerimaan negara, agar sesuai dengan anggaran pendapatan dan belanja negara (APBN)

Fakor lain yang menyebabkan penghindaran pajak adalah ketidakjelasan peraturan perpajakan, kekurangwajaran dan ketidakmerataan juga dapat menyebabkan dilakukannya penghindaran pajak. Hal ini berkaitan dengan azas keadilan dan ketidakmerataan, dimana ketika pajak dibayarkan maka harus dirasakan manfaatnya yang berhubungan dengan pelayanan publik yang dilakukan pemerintah. Tingkat kepercayaan wajib pajak telah hilang/luntur karena unsur-unsur dari sistem perpajakan itu sendiri. Kinerja sistem perpajakan yang kurang maksimal seperti kurang selarasnya antara kebijakan pusat dan daerah serta administrasi kantor yang korupsi sehingga memungkinkan dilakukannya penghindaran pajak.

Perilaku penghindaran pajak dapat diukur dengan beberapa cara, salah satunya adalah sengan Cash Earning Tax Ratio (CETR) yang dilakukan dengan membandingkan antara kas yang dikeluarkan untuk membayar pajak dan laba sebelum pajak (Budiman dan Setiyono, 2012).

Penghindaran pajak yang dilakukan juga akan berhubungan dengan profitabilitas yang dihasilkan oleh perusahaan karena salah satu pengukur kinerja suatu perusahaan adalah profitabilitas. Profitabilitas suatu perusahaan menggambarkan kemampuan perusahaan dalam menghasilkan laba atau untuk mengukur seberapa efektif manajemen suatu perusahaan. Untuk mengukur kinerja perusahaan dalam menghasilkan laba dari pengelolaan aktiva dengan profitabilitas yaitu menggunakan Return On Assets (ROA), Kegiatan pendanaan Leverage dan ukuran perusahaan.

Pada tahun 2019, pemerintah melalui Direktorat Jenderal Pajak (DJP) sedang mendalami kegiatan penghindaran pajak (Tax Avoidance) yang dilakukan oleh perusahaan batu bara PT Adaro Energy Tbk dengan skema transfer pricing melalui anak perusahaan yang berada di Singapura. Dugaan penghindaran pajak yang dilakukan oleh Adaro Energy Tbk ini dilaporkan oleh Global Witness, dimana dalam 
laporan tersebut PT Adaro Energy Tbk diindikasi melarikan pendapatan dan labanya ke luar negeri, sehingga dapat menekan pajak yang dibayarkan kepada pemerintah indonesia. (Tirto.id, diakses tanggal 15 November 2020)

Dan dalam penelitian ini data yang digunakan yaitu dari perusahaan manufaktur yang terdaftar di Bursa Efek Indonesia periode 2015-2019. Alasan pemilihan perusahaan manufaktur khususnya pada sektor industri barang konsumsi adalah karena perusahaan yang bergerak di bidang ini cukup diminati oleh para investor, sebab telah dibuktikan melalui daya tahan sektor manufaktur terutama ditopang oleh sektor konsumer yang ditandai dengan bertambahnya jumlah penduduk. Dengan bertambahnya jumlah penduduk akan memungkinkan semakin bertambah pula konsumen yang akan membeli produk perusahaan yang disertai dengan pembayaran beban pajak atas pembelian produk tersebut misal dengan adanya Pajak Pertambahan Nilai (PPN), sehingga sektor industri barang konsumsi berkontribusi besar dalam penerimaan pajak.

Dalam penelitan ini menggunakan Teori Stewardship mengasumsikan hubungan yang kuat antara kesuksesan organisasi dengan kepuasan pemilik. Menurut Putri (2015) Ketika kepentingan pemilik dan steward tidak sama, steward akan berusaha bekerja sama daripada menentangnya, karena steward merasa kepentingan bersama dan berperilaku sesuai dengan perilaku pemilik merupakan pertimbangan yang rasional karena steward lebih melihat pada usaha untuk mencapai tujuan organisasi. Dan juga menggunakan teori sinyal , dimana menurut Artaningrum dan Pradnyani (2020) mengatakan bahwa teori sinyal menekankan kepada pentingnya informasi yang dikeluarkan oleh perusahaan terhadap keputusan investasi pihak di luar perusahaan. Informasi merupakan unsur penting bagi investor dan pelaku bisnis karena informasi pada hakekatnya menyajikan keterangan, catatan atau gambaran baik untuk keadaan masa lalu, saat ini maupun keadaan masa yang akan datang bagi kelangsungan hidup perusahaan 
ISSN Cetak : 2087-0434

E-ISSN $\quad: 2599-0810$

\section{METODE PENELITIAN}

Penelitan ini menggunakan sampel perusahaan yang melakukan penawaran umun di Bursa Efek Indonesia dari tahun 2015 hingga 2019 dan meruapakan prusahaan farmasi. Dan dari perusahaan farmasi yang masuk ke Bursa Efek Indonesia terdapat sampel 8 perusahaan farmasi yang masuk kedalam kriteria.

Variabel yang digunakan dalam penelitian ini dibedakan menjadi dua macam, yaitu variable dependen dan variable independen. Dalam penelitian ini yang menjadi variabel dependen yaitu penghindaran pajak. Sedangkan yang menjadi variabel independen adalah Profitabilitas, Leverage, dan Ukuran Perusahaan. Adapun definisi operasional variabelnya adalah sebagai berikut:

\section{a. Penghindaran Pajak}

Menurut Suandy (2011) penghindaran pajak merupakan upaya untuk melakukan penghematan dan meminimlisasi pajak yang dapat dilakukan secara legal melalui manajemen pajak.

\section{b. Profitabilitas}

Profitabilitas adalah rasio yang digunkaan untuk menentukan kemampuan perusahaan dalam menghasilkan laba atau seberapa efektif manajemen sebuah perusahaan (Syahyunan, 2015). Semakin besar laba yang dihasilkan oleh perusahaan maka semakin besar pula beban pajak yang harus dibayar oleh perusahaan.

\section{c. Leverage}

Laverage adalah tingkatan hutang yang digunakan perusahaan dalam pembiayaan. Perusahaan yang menggunakan hutang pada komposisi pembiayaan, akan ada beban bunga yang harus dibayar. Semakin tinggi rasio laverage, maka semakin tinggi biaya bunga yang timbul dari hutang. Dan semakin tinggi biaya bunga, maka akan mempengaruhi penurunan beban pajak perusahaan.

\section{d. Ukuran Perusahaan}

Ukuran Perusahaan digambarkan melalui total aset, total penjualan, rata-rata total penjualan aset dan rata-rata total aset. Ukuran perusahaan yang diukur dari total aset akan ditransformasikan dalam bentuk logaritma dengan tujuan untuk menyamakan dengan variabel lain, karena nilai total aset perusahaan 


ISSN Cetak : : 2087-0434

E-ISSN $\quad: 2599-0810$

relatif lebih besar dibandingkan dengan variabel-variabel lain dalam penelitian ini.

Tabel 1 : Operasionalisasi Variabel Penelitian

\begin{tabular}{|c|c|c|c|}
\hline Variabel & Indikator & & Skala \\
\hline \multirow{2}{*}{$\begin{array}{l}\text { Penghindaran } \\
\text { Pajak (Y) }\end{array}$} & \multirow{2}{*}{ CETR = } & n Pajak & \multirow{2}{*}{ Rasio } \\
\hline & & m Pajak & \\
\hline \multirow{2}{*}{$\begin{array}{l}\text { Profitabilitas } \\
\text { (X1) }\end{array}$} & $R O A=$ & elah pajak & \multirow[t]{2}{*}{ Rasio } \\
\hline & \multirow{3}{*}{ Debt to Equity Ratio = } & Aset & \\
\hline \multirow{2}{*}{ Leverage (X2) } & & Jumlah Utang & \multirow[t]{2}{*}{ Rasio } \\
\hline & & Modal Sendiri & \\
\hline $\begin{array}{l}\text { Ukuran } \\
\text { Perusahaan (X3) }\end{array}$ & \multicolumn{2}{|c|}{ Size $=L_{n}($ Total Aset $)$} & Rasio \\
\hline
\end{tabular}

Sumber : Data yang diolah

HASIL DAN PEMBAHASAN

Tabel 2 : Statistifk Deskriptip

\begin{tabular}{lrrrrr}
\hline & N & Minimum & Maximum & Mean & $\begin{array}{l}\text { Std. } \\
\text { Deviation }\end{array}$ \\
\hline Profitabilitas & 40 &, 00 &, 23 &, 0995 &, 05729 \\
Leverage & 40 &, 08 & 13,98 & 1,0803 & 2,28026 \\
\hline Ukuran_Perusahaan & 40 & 25,80 & 30,64 & 28,4890 & 1,39434 \\
Penghindaran pjak & 40 &, 28 & 1,41 &, 4075 &, 18489 \\
& & & & & \\
\hline
\end{tabular}

Tabel diatas merupakan hasil statistik deskriptif dari data yang dikumpulkan sehingga dapat dijelaskan analisisnya adalah sebagai berikut:

a. Hasil staitistik deskriptif mengenai variabel Profitabilitas menunjukkan bahwa nilai paling kecil (minimum) sebesar 0,00 yang didapat oleh PT Kimia Farma Tbk. pada tahun 2019. Sedangkan nilai paling besar (maksimum) sebesar 0,23 yang didapat oleh PT Industri Jamu dan Farmasi Sido Muncul Tbk. pada tahun 2019.

b. Hasil staitistik deskriptif mengenai variabel Leverage menunjukkan bahwa nilai paling kecil (minimum) sebesar 0,08 yang didapat oleh PT Industri Jamu dan Farmasi Sido Muncul Tbk. pada tahun 2015 dan 2016. Sedangkan nilai 
paling besar (maksimum) sebesar 13,98 yang didapat oleh PT Merck Sharp Dohme Pharma Tbk. pada tahun 2018.

c. Hasil staitistik deskriptif mengenai variabel Ukuran Perusahaan menunjukkan bahwa nilai paling kecil (minimum) sebesar 25,80 yang didapat oleh PT Pyridam Farma Tbk. pada tahun 2015 dan 2017. Sedangkan nilai paling besar (maksimum) sebesar 30,64 yang didapat oleh PT Kalbe Farma Tbk. pada tahun 2019.

d. Hasil staitistik deskriptif mengenai variabel Penghindaran Pajak menunjukkan bahwa nilai paling kecil (minimum) sebesar 0,28 yang didapat oleh PT Industri Jamu dan Farmasi Sido Muncul Tbk. pada tahun 2015 dan 2017. Sedangkan nilai paling besar (maksimum) sebesar 1,41 yang didapat oleh PT Kimia Farma Tbk. pada tahun 2019.

\section{UJI HIPOTESIS}

Tabel 3 :Hasil Regresi Linear Berganda

\begin{tabular}{|c|c|c|c|c|c|}
\hline \multirow[b]{2}{*}{ Model } & \multicolumn{2}{|c|}{$\begin{array}{l}\text { Unstandardized } \\
\text { Coefficients }\end{array}$} & \multirow{2}{*}{$\begin{array}{c}\begin{array}{r}\text { Standardized } \\
\text { Coefficients }\end{array} \\
\text { Beta }\end{array}$} & \multirow[b]{2}{*}{$\mathrm{t}$} & \multirow[b]{2}{*}{ Sig. } \\
\hline & B & $\begin{array}{l}\text { Std. } \\
\text { Error }\end{array}$ & & & \\
\hline (Constant) &,- 121 &, 578 & &,- 209 &, 835 \\
\hline Profitabilitas & $-1,270$ & ,504 &,- 393 & $2,520^{-}$ & ,016 \\
\hline Leverage & ,011 & ,012 &, 140 & ,920 &, 364 \\
\hline $\begin{array}{l}\text { Ukuran_Perus } \\
\text { ahaan }\end{array}$ & ,023 & ,021 & ,170 & 1,098 & ,280 \\
\hline
\end{tabular}

Dependent Variable: Penghindaran Pajak

Adapun interpretasi dari persamaan regresi linear tersebut adalah sebagai berikut:

a. Berdasarkan data diatas, menunjukkan nilai konstanta penghindaran pajak sebesar $-0,121$. Koefisien negatif mengandung arti bahwa pengaruh variabel lain yang tidak dijelaskan dalam model regresi memiliki hubungan terbalik dengan penghindaran pajak. Oleh karena itu, nilai konstanta sebesar -0,121 memiliki makna apabila variabel profitabilitas, leverage, dan ukuran perusahaan adalah 0 maka terjadi penghindaran pajak sebesar 0,121 . 
b. Profitabilitas mempunyai koefisien regresi sebesar -1,270. Jika diasumsikan variabel independen lainnya konstan, maka setiap kenaikan satu satuan profitabilitas akan berdampak pada kenaikan variabel penghindaran pajak sebesar 1,270 .

c. Leverage mempunyai koefisien regresi sebesar 0,011. Maka dapat disimpulkan bahwa setiap kenaikan variabel leverage sebesar satu satuan akan berdampak pada penurunan variabel penghindaran pajak sebesar 0,011 dengan asumsi variabel independen lainnya konstan.

d. Ukuran perusahaan mempunyai koefisien regresi sebesar 0,023. Dan jika diasumsikan semua variabel independennya konstan, maka setiap kenaikan satu satuan ukuran perusahaan akan berdampak pada penurunan variabel penghindaran pajak sebesar 0,023 .

\section{Pengaruh Profitabilitas terhadap Penghindaran Pajak}

Hipotesis pertama (H1) menyatakan bahwa Profitabilitas berpengaruh negatif terhadap pengindaran pajak pada perusahaan manufaktur sub sektor farmasi yang terdaftar di BEI periode 2015-2019. Berdasarkan pengujian yang telah dilakukan H1 dinyatakan diterima.

Ketika perusahaan mempunyai tingkat profitabilitas yang tinggi maka manajamen perusahaan telah mampu membuat sebuah perencanaan pajak secara optimal. Prakosa (2014) dalam Arianandini dan Ramantha (2018) mengatakan bahwa perusahaan yang memiliki perencanaan yang baik maka akan memperoleh pajak yang optimal, sehingga berakibat pada menurunnya kegiatan penghindaran pajak yang dilakukan oleh perusahaan. Slemrod (1989) dalam Arianandini dan Ramantha (2018) mengatakan bahwa perusahaan yang mempunyai profitabilitas tinggi cenderung akan melaporkan pajaknya dengan jujurdari pada.

Perusahaan dengan profitabilitas yang rendah. Dan menurut Chen et al. (2010) dalam Arianandini dan Ramantha (2018) menyatakan bahwa perusahaan dengan profitabilitas rendah pada umumnya mengalami kesulitan keuangan (financial difficulty) dan cenderung akan melakukan ketidakpatuhan pajak. Perusahaan yang memiliki profitabilitas tinggi memiliki kesempatan untuk 
memposisikan diri dalam tax planning yang dapat mengurangi jumlah beban kewajiban perpajakan.

Adapun hasil penelitian ini sejalan dengan penelitian yang telah dilakukan oleh Hidayat (2018) yang menyatakan bahwa Profitabilitas berpengaruh negatif terhadap Penghindaran Pajak.

\section{Pengaruh Leverage terhadap Penghindaran Pajak}

Hipotesis kedua (H2) menyatakan bahwa Leverage berpengaruh positif terhadap pengindaran pajak pada perusahaan manufaktur sub sektor farmasi yang terdaftar di BEI periode 2015-2019. Berdasarkan hasil pengujian yang telah dilakukan $\mathrm{H} 2$ dinyatakan ditolak, sehingga dapat disimpulkan bahwa Leverage tidak berpengaruh terhadap pengindaran pajak pada perusahaan manufaktur sub sektor farmasi yang terdaftar di BEI periode 2015-2019.

Dalam penelitian yang dilakukan oleh Permata, dkk (2018) mengatakan bahwa perusahaan yang melakukan pendanaan yang berasal dari utang untuk kegiatan operasionalnya akan menimbulkan rasio utang yang tinggi dan beban bunga yang harus dibayarkan akan semakin besar sehingga perusahaan akan mempertimbangkan untuk tidak melakukan pendanaan dengan utang secara besar-besaran. Karena ketika perusahaan mempunyai tingkat leverage yang tinggi maka akan dipandang sebagai perusahaan yang kurang sehat.

Hasil penelitian ini sejalan dengan penelitian yang dilakukan oleh Puspita dan Febrianti (2017), Hidayat (2018), dan Sonia dan Suparmun (2018) yang menyatkan bahwa Leverage tidak berpengaruh terhadap Penghindaran Pajak.

\section{Pengaruh Ukuran Perusahaan terhadap Penghindaran Pajak}

Hipotesis ketiga (H3) menyatakan bahwa Ukuran Perusahaan berpengaruh positif terhadap pengindaran pajak pada perusahaan manufaktur sub sektor farmasi yang terdaftar di BEI periode 2015-2019. Dari hasil pengujian yang telah dilakukan menyatakan bahwa H3 ditolak sehingga dapat disimpulkan bahwa Ukuran Perusahaan tidak berpengaruh terhadap pengindaran pajak pada perusahaan manufaktur sub sektor farmasi yang terdaftar di BEI periode 2015-2019. 
Berdasarkan penelitian yang telah dilakukan oleh Permata, dkk (2018) yang mengatakan bahwa untuk perusahaan berukuran besar maupun kecil akan lebih berhati-hati dalam mengambil keputusan terkait pembayaran pajak, karena jika tidak maka akan menimbulkan kerugian bagi perusahaan. Dan juga perusahaan cenderung tidak ingin mengambil resiko yang ditimbulkan dari pemeriksaan ataupun dikenakannya sanksi yang akan menimbulkan citra buruk bagi perusahaan.

Hasil penelitian ini sejalan dengan penelitian yang dilakukan oleh Sonia dan Suparmun (2018) yang menyatakan bahwa Ukuran Perusahaan tidak berpengaruh terhadap Penghindaran Pajak

\section{KESIMPULAN}

Berdasarkan hasil penelitan yang diperolah yang diperolah dari hasil statistik dan pembahasan, maka dapat disimpulkan bahwa profitabilitas bepengaruh profitabilitas berpengaruh negatif terhadap penghindaran pajak. Sedangkan leverage dan ukuran perusahaan tidak berpengaruh terhadap penghindaran pajak pada perusahaan manufaktur.

Keterbatan penelitan ini adalah dari populasi yang diperoleh terdapat beberapa perusahaan yang tidak memenuhi kritera sehingga sampel yang diperoleh tidak sesuai dengan yang diharapkan. Bagi penelitian selanjutnya, diharapkan penentuan populasi perusahaan sesuai dengan kriterian penilian, sehingga populasi yang diperolah akan lebih banyak. Untuk metode pengukuran variabel baik variabel independen maupun variabel dependennya dapat menggunakan model pengukuran lain. Seperti Penghindaran Pajak dengan ETR (Earning Tax Rate). Karena cara lain untuk mengetahui efektifitas dari pembayaran pajak perusahaan yaitu dengan ETR (Earning Tax Rate), dimana pembayaran pajak akan dibandingkan dengan laba sebelum pajak. 
ISSN Cetak : 2087-0434

E-ISSN $\quad: 2599-0810$

\section{DAFTAR REFERENSI}

Abdullah, Ikhsan. (2020). Pengaruh Likuiditas Dan Leverage Terhadap Penghindaran Pajak Pada Perusahaan Makanan Dan Minuman. Jurnal Riset Akuntansi dan Bisnis Vol . 20, No.1, 2020, hal 16-22.

Alfina, I. T, Nurlela, dan Wijayanti, A. (2018)._The Influence of Profitability, Leverage, Independent Commissioner, and Company Size to Tax Avoidance. The 2nd International Conference on Technology, Education, and Social Science 2018.

Arianandini, P. W, dan Ramntha, I. W. (2018). Pengaruh Profitabilitas dan Kepemilikan Institusional pada Tax Avoidance. E-jurnal Akuntansi Universitas Udayana. Vol. 33 hal. 2088-2116 ISSN: 2302-8556.

Artaningrum, R, G., dan Pradnyani, N, L, P, S, P. (2020). Pengaruh Good Coorporate Governance, Profitabilitas, dan Ukuran Perusahaan terhadap Penghindaran Pajak. E-Jurnal Akuntansi Universitas Udayana, Vol. 15 No. 2, Hal 131-138.

Chen, S., Chen, X., Cheng, Q., Shevlin, T. (2010). Are Family Firms More Tax Aggressive Than Non-Family Firms? Journal of Financial Economics. 95, 41-61.

Darmawan, I, G, H, dan Sukarta, I, M. 2014. Pengaruh Penerapan Corporate Governance, Leverage, Return On Assets, Dan Ukuran Perusahaan Pada Penghindaran Pajak. EJurnal Akuntansi Universitas Udayana. 9.1 (2014): 143-161. ISSN: 2302-8556.

Davis, J. H., Schoorman, F. D., \& Donaldson, L. (1997). Toward a Stewardship Theory of Management. Academy of Management Review, 22, 20-47.

Desai, M.A. \& Dharmapala, D. (2006). "Corporate Tax Avoidance and HighPowered Incentives”. Journal of Financial Economics, 79, Hal. 145- 179.

Dewinta, I, A, dan Ery, P. (2016). Pengaruh ukuran perusahaan, umur perusahaan, profitabilitas, leverage, dan pertumbuhan penjualan terhadap tax avoidance. EJournal Akuntansi Universitas Udayana. Vol. 14, 1584 -1613.

Hoque, M. J., Bhuiyan, M. Z. H., Ahmad, A. (2011). Tax Evasion and Avoidance Crimes - A Study on Some Corporate Firms of Bangladesh. Tax management.

Ida Ayu. R dan Putu Ery S. (2016). Pengaruh ukuran perusahaan, umur perusahaan,Profitabilitas,Leverage, dan pertumbuhan pnjualan terhadap Tax. EJurnal Akuntansi Universitas Udayana Vol.14.3. Maret 2016: 1584-161 ISSN: 230285563.

Marlinda, Diana Eva, dkk. (2020). Pengaruh Gcg, Profitabilitas, Capital Intensity, dan Ukuran Perusahaan terhadap Tax Avoidance. Ekonomis: Journal of Economics and Business, 4(1), Maret 2020: 39-47.

Musyarofah, E. (2016), "Pengaruh derifatif keuangan, leverage, dan ukuran perusahaan terhadap Penghindaran Pajak” Skripsi : Universitas Islam Negeri Syarif Hidayatullah Jakarta. 
ISSN Cetak : :2087-0434

E-ISSN : :2599-0810

Nurfadilah, H. Mulyati, M. Purnamasari and H. Niar. (2016). Pengaruh leverage, ukuran perusahaan dan kualitas audit terhadap penghindaran pajak. Syariah Paper Accounting FEB UMS

Permata, A. D, Nurlela, S, dan Masitoh, W. (2018). Pengaruh Size, Age, Profitability, Leverage dan Sales Growth Terhadap Tax Avoidance. Jurnal Akuntansi dan Pajak, 19(01), 2018, 10-20.

Prasiwi, K, W., dan Harto, P. (2015). Pengaruh Penghindaran Pajak terhadap Nilai Perusahaan: Transparansi Informasi sebagai variabel pemoderasi. Doctoral Dissertation, Fakultas Ekonomika dan Bisnis.

Puspita, Deanna dan Febrianti, Meiriska. (2017). Faktor-faktor yang mempengaruhi Penghindaran Pajak pada Perusahaan Manufaktur Bursa Efek Indonesia. Jurnal Bisnis dan Akuntansi. Vol. 19 No. 1 Hal. 38-46

Putra, I, G, L, N, D, C, dan Merkusiwati, N, K, L, A. (2016). Pengaruh komisaris independen, leverage, size dan capital intensity ratio pada tax avoidance. E-Jurnal Akuntansi Universitas Udayana. Vol. 17. 690-714.

Putra, W. E, Yuliusman, dan Wisra, R.F. (2020). The Relations Among Firm Characteristic, Capital Intensity, Institutional Ownership, And Tax Avoidance: Some Evidence From Indonesia. Humanities \& Social Sciences Reviews. EISSN: 2395-6518, Vol 8, No 1, 2020, 315-322.

Putri, Rachma Kartika. 2015. Pengaruh Manajemen Keluarga Terhadap Penghindran Pajak. AKRUAL 7 (1) (2015): 60-72.

Rokhmah, Ainur. (2019). Pengaruh Tax Avoidance terhadap Kinerja Perusahaan. Jurnal Akuntansi Integratif, Vol. 5 No.2, Hal 96-108.

Santoso, I., \& Rahayu, N. (2013). Corporate Tax Management. Jakarta: Observation \& Research of Taxation (ortax).

Sonia, dan Suparmun, Haryo. (2018). Factors Influencing Tax Avoidance. Advances in Economics, Business and Management Research. Vol 73.

Subagiastra, dkk. (2016). Pengaruh Profitabilitas, Kepemilikan Keluarga, Dan Goo Corporate Governance Terhadap Penghindaran Pajak. Jurnal Ilmiah Akuntansi • Vol. 1, No. 2, Hal: 167-193. Desember 2016.

Tandean, V. A., \& Winnie. (2016). The Effect of Good Corporate Governance on Tax Avoidance: An Empirical Study on Manufacturing Companies Listed in IDX period 2010-2013. Asian Journal of Accounting Research , pp- 28- 38, Vol.1.1. 
ISSN Cetak : :2087-0434

E-ISSN $\quad: 2599-0810$

Wijayanti, Y. C., dan Ni Ketut Lely A.Merkusiwati. (2017). Pengaruh Proposi Komisaris Independen, Kepemilikan Institusional, Leverage, Dan Ukuran Perusahaan Pada Penghindaran Pajak. E-Jurnal Akuntansi Universitas Udayana, Vol 20, No 1, Hal 699-728. 